\title{
Effect of NPK Fertilizer Rates on Growth and Yield of Field and Greenhouse Grown Pepino Melon (Solanum muricatum Aiton)
}

\author{
Carol Mwende Mutua ${ }^{1, a^{*}}$, Joshua Otieno Ogweno ${ }^{1, b}$ \\ and Robert Morwani Gesimba ${ }^{1, c}$
${ }^{1}$ Department of Crops, Horticulture and Soils, Egerton University, P. O. Box 536-20115, Egerton, Nakuru, Kenya \\ a*carolmutua713@yahoo.com, bjogweno@egerton.ac.ke, crobert.gesimba@egerton.ac.ke
}

Keywords: Pepino melon, NPK fertilizer, plant growth, yield, field, greenhouse

\begin{abstract}
Pepino melon (Solanum muricatum Ait.) is an exotic vegetable whose consumption is on the increase in Kenya due to its health and nutritional benefits. A study was conducted at Egerton University, Kenya in 2018-2019 to investigate the effect of NPK fertilizer rates $(0,100,200.300$ and $400 \mathrm{~kg} \mathrm{ha}^{-1}$ ) on growth and yield of field and greenhouse grown pepino melons. The experiment was laid in a randomized complete block design with three replications. Data was recorded on plant height, stem diameter, number of leaves per bush, number of branches, days to $50 \%$ flowering, fruit weight and total yield. Data were analyzed using analysis of variance with the SAS statistical package. Significant means were separated using Tukey's Honestly Significant Difference at $p \leq 0.05$. Results indicated that NPK fertilizer rates and growing environment influenced growth and yield of pepino melon. At 100 DAP plants grown in the greenhouse and supplied with $200 \mathrm{~kg} \mathrm{NPK} \mathrm{ha}^{-1}$ had a stem diameter of $14.01 \mathrm{~mm}$ which was significantly bigger $p \leq 0.05$ compared to those grown in the field and supplied with $300 \mathrm{~kg} \mathrm{NPK} \mathrm{ha}{ }^{-1}$ with a stem diameter of $11.71 \mathrm{~mm}$ in trial two. Application of $300 \mathrm{~kg} \mathrm{NPK} \mathrm{ha}{ }^{-1}$ for field grown pepino melons gave the highest yield of $1102.48 \mathrm{~kg} \mathrm{ha}^{-1}$ and $1060.55 \mathrm{~kg} \mathrm{ha}^{-1}$ in trial one and two respectively. In conclusion, application of $300 \mathrm{~kg} \mathrm{ha}^{-1}$ of NPK fertilizer for field grown pepino melon is recommended.
\end{abstract}

\section{Introduction}

Pepino melon (Solanum muricatum Ait.) is an exotic vegetable which belongs to the family solanaceae [1]. The fruit was initially grown in South America but its cultivation has extended to Australia, New Zealand, USA [2] Central America, Morocco, Spain, Israel and the highlands of Kenya [3]. The vegetable was introduced in Kenya in 2013 and its consumption in Kenya is increasing due to its health, nutritional and economic value [4]. The edible part is the fruit which is aromatic and juicy [5]. The fruit can be eaten when mature green as a vegetable in stews [1] and the ripe fruit is eaten as a dessert fruit, in salads and ice creams [5].

Pepino is low in calories but very rich in minerals such as calcium, phosphorous and potassium and vitamins A, B1, B2, B3 and C [6]. The fruit varies in size and shape depending on the cultivar and the colour ranges from completely purple, solid green or green with purple stripes, or cream colored with or without purple stripes [7]. The main challenge in vegetable production is nutrient deficiency due to improper use of fertilizers [8]. Proper vegetable growth requires ideal nutrient supply [9]. In the tropics, soil fertility is declining due to excessive rainfall and continuous cultivation has led to lack of essential nutrients in the soil [10]. NPK fertilizer has the ability to release nutrients very fast into the soil and thus help sustain soil fertility and crop production [11]. The present study aimed at investigating the effects of different rates of NPK fertilizer on growth and yield of field and greenhouse grown pepino melons. 


\section{Materials and Methods}

\section{Site Description}

The experiment was conducted at the Horticulture Research and Teaching Field, Egerton University, Njoro. The field lies at a latitude of $0^{\circ} 23^{\prime}$ South, longitudes $35^{\circ} 35^{\prime}$ East in the Lower Highland III Agro Ecological Zone (LH3) at an altitude of approximately 2,238 m above sea level [12]. Average maximum and minimum temperatures range from $19{ }^{\circ} \mathrm{C}$ to $22{ }^{\circ} \mathrm{C}$ and $5{ }^{\circ} \mathrm{C}$ to $8{ }^{\circ} \mathrm{C}$, respectively, with a total annual rainfall ranging from 1200 to $1400 \mathrm{~mm}$. The soils are predominantly mollic andosols [12].

\section{Experimental design and treatment application}

The experimental design was Randomized Complete Block Design (RCBD) with five treatments and three replications. The five treatments include $\left(0,100,200,300\right.$ and 400 NPK (17:17:17) $\left.\mathrm{kg} \mathrm{ha}^{-1}\right)$. Pepino seedlings (Ecuadorian Gold variety) were obtained from Garlic and Pepino Farm, Nakuru, Kenya. For the field experiment, each experimental plot was $3.2 \mathrm{~m} \times 3.2 \mathrm{~m}$ and the seedlings were planted in rows $80 \mathrm{~cm}$ apart and $50 \mathrm{~cm}$ within the plants to give a total of 24 plants per plot [13]. In the greenhouse experiment, each experimental plot was $2 \mathrm{~m} \times 5 \mathrm{~m}$ at the same spacing as in the field experiment to give a total of 25 plants per plot. Soil samples were collected from the experimental plots in the field and greenhouse and analyzed for total $\mathrm{N}, \mathrm{P}, \mathrm{K}$ and $\mathrm{pH}$ before the experiment using the method described by [14]. NPK fertilizer was applied and thoroughly mixed with the soil before placing the seedlings in the transplanting holes. Weeding was done uniformly to all experimental units. Field capacity was determined as described by Cong [15] thereafter tensiometers were placed in two experimental units in each block. Irrigation was done when the field capacity fell below $60 \%$ because pepino requires a field capacity of $60-65 \%$ [16]. Drip irrigation was used in the greenhouse and it supplied about 180 liters to the 375 plants in the greenhouse.

\section{Data collection}

Data was collected and recorded on the following parameters from a total of 8 plants from the two middle rows of each plot. The outer rows in each plot served as guard rows.

i) Plant height: This was determined from the ground to the tip of the plant by means of a tape measure. This was done at an interval of 14 days starting 30 days after planting up to 100 days after planting.

ii) Stem diameter: The same pepino plants used to measure plant height were used to measure stem thickness at the ground level using vanier calipers (in $\mathrm{mm}$ ) once after every 14 days starting from 30 days after planting up to 100 days after planting.

iii) Number of leaves per bush before flowering: Number of leaves were counted from the selected plants just before flowering. A mean number of branches was computed for each experimental plot.

iv) Number of branches: The number of primary branches was determined by counting from the selected plants from each plot and replicate at the peak of vegetative phase, just before flowering. A mean number of branches was computed for each plot from the 8 selected plants.

v) Days to 50\% flowering: The number of days taken by the selected plants in each experimental plot to attain $50 \%$ flowering was determined. Thereafter, the mean number of days taken to attain $50 \%$ flowering in each experimental plot was computed.

vi) Fruit Weight: Mature fruits were harvested and then weighed on electronic weighing machine (JA10003) to determine fruit weight (g) per plant in each treatment.

vii) Total yield: Mature fruits were harvested and weighed on an electronic weighing machine (JA10003) to determine total yield $\left(\mathrm{kg} \mathrm{ha}^{-1}\right)$ in each treatment.

\section{Data analysis}

Data collected was subjected to Analysis of Variance (ANOVA) and significant means separated using Tukey's honestly significant difference (Tukey's HSD) test at $p \leq 0.05$. The SAS statistical package [17] was used for data analysis. 


\section{Results}

\section{Pre-planting soil analysis}

The result of the pre-planting soil analysis (to affirm the soil conditions) are presented in Table 1.

Table 1: Pre-planting soil analytical results

\begin{tabular}{lllll}
\hline Soil properties & Field & \multicolumn{3}{c}{ Greenhouse } \\
\cline { 2 - 5 } & Trial 1 & Trial 2 & Trial 1 & Trial 2 \\
\hline Total Nitrogen $(\%)$ & $0.28-0.45$ & $0.21-0.40$ & $0.21-0.78$ & $0.20-0.72$ \\
Potassium $(\mathrm{mg} / \mathrm{kg})$ & $12.6-22.13$ & $10.2-20.45$ & $19.4-48.6$ & $17.5-38.7$ \\
Available P (mg/kg) & $1.31-1.72$ & $1.23-1.63$ & $1.96-3.06$ & $1.88-2.99$ \\
$\mathrm{pH}($ water) & $4.8-5.7$ & $4.6-5.2$ & $4.38-6.03$ & $4.25-6.00$ \\
\hline
\end{tabular}

\section{Temperature data}

The results of average monthly temperature in the field and greenhouse are presented in Table 2.

Table 2: Average monthly field and greenhouse temperature $\left({ }^{\circ} \mathrm{C}\right)$ in trial one and two

\begin{tabular}{lllllllll}
\hline & & & & & & & & \\
\multirow{4}{*}{ Trial one } & Environment & 2018 & & & 2019 & & & \\
& & Nov & Dec & Jan & Feb & Mar & Apr & May \\
& Greenhouse & 30.3 & 21.0 & 33.4 & 30.2 & 29.4 & 34.0 & 35.8 \\
\hline \multirow{3}{*}{ Trial two } & & & 2019 & & & & & 2020 \\
& & July & Aug & Sept & Oct & Nov & Dec & Jan \\
& Greenhouse & 19.1 & 19.2 & 20.5 & 19.3 & 19.3 & 18.9 & 19.1 \\
& & 29.4 & 30.0 & 28.0 & 32.0 & 28.0 & 35.3 \\
\hline
\end{tabular}

Plant height: NPK fertilization and growing environment had a significant effect on plant height in both trials. Plants which were supplied with $200 \mathrm{~kg} \mathrm{NPK} \mathrm{ha}^{-1}$ and grown in the greenhouse were significantly taller at $\mathrm{p} \leq 0.05$ than the other NPK rates though not significantly different at $p \leq 0.05$ from those supplied with $300 \mathrm{~kg}$ NPK ha ${ }^{-1}$ grown in the field in both trial one and two. The same trend was observed from 30 to 100 DAP. In trial two, 44 DAP plants supplied with $200 \mathrm{~kg} \mathrm{ha}^{-1}$ were significantly different from those supplied with $300 \mathrm{~kg} \mathrm{ha}^{-1}$ in the field (Table 3). Generally, it was noted that plant height increased from 30 DAP to 100 DAP. Plants which were planted in the greenhouse were generally taller than those grown in the field in both trials (Table 4).

Table 3: Effect of NPK fertilizer rates and growing environment on plant height $(\mathrm{cm})$ of pepino melon in trial one

\begin{tabular}{llllllll}
\hline Environment & $\begin{array}{l}\text { Fertilizer } \\
\left(\mathrm{kg} \mathrm{ha}^{-1}\right)\end{array}$ & $30 \mathrm{DAP}$ & 44 DAP & 58 DAP & 72 DAP & 86 DAP & 100 DAP \\
\hline Greenhouse & $0 \mathrm{~kg}$ & $16.79 \mathrm{e}$ & $26.13 \mathrm{c}$ & $36.38 \mathrm{c}$ & $44.54 \mathrm{~d}$ & $52.66 \mathrm{~cd}$ & $56.50 \mathrm{bcd}$ \\
& $100 \mathrm{~kg}$ & $23.92 \mathrm{bcd}$ & $39.34 \mathrm{~b}$ & $50.63 \mathrm{~b}$ & $55.34 \mathrm{c}$ & $62.00 \mathrm{~b}$ & $52.63 \mathrm{~cd}$ \\
& $200 \mathrm{~kg}$ & $35.79 \mathrm{a}$ & $55.58 \mathrm{a}$ & $62.88 \mathrm{a}$ & $69.34 \mathrm{a}$ & $76.67 \mathrm{a}$ & $77.00 \mathrm{a}$ \\
& $300 \mathrm{~kg}$ & $25.08 \mathrm{bc}$ & $38.50 \mathrm{~b}$ & $48.00 \mathrm{~b}$ & $56.92 \mathrm{bc}$ & $60.09 \mathrm{bc}$ & $63.67 \mathrm{~b}$ \\
& $400 \mathrm{~kg}$ & $26.54 \mathrm{~b}$ & $38.83 \mathrm{~b}$ & $46.55 \mathrm{~b}$ & $55.25 \mathrm{c}$ & $61.25 \mathrm{bc}$ & $60.38 \mathrm{bc}$ \\
Field & $0 \mathrm{~kg}$ & $18.46 \mathrm{de}$ & $21.54 \mathrm{c}$ & $25.25 \mathrm{~d}$ & $31.87 \mathrm{e}$ & $41.83 \mathrm{e}$ & $48.58 \mathrm{~d}$ \\
& $100 \mathrm{~kg}$ & $21.08 \mathrm{bcde}$ & $23.96 \mathrm{c}$ & $28.13 \mathrm{~d}$ & $36.92 \mathrm{de}$ & $47.58 \mathrm{de}$ & $52.92 \mathrm{~cd}$ \\
& $200 \mathrm{~kg}$ & $21.79 \mathrm{bcde}$ & $23.87 \mathrm{c}$ & $28.83 \mathrm{~cd}$ & $36.25 \mathrm{de}$ & $46.38 \mathrm{de}$ & $52.84 \mathrm{~cd}$ \\
& $300 \mathrm{~kg}$ & $35.35 \mathrm{a}$ & $52.50 \mathrm{a}$ & $61.44 \mathrm{a}$ & $66.29 \mathrm{ab}$ & $72.63 \mathrm{a}$ & $74.83 \mathrm{a}$ \\
& $400 \mathrm{~kg}$ & $20.92 \mathrm{cde}$ & $22.29 \mathrm{c}$ & $29.25 \mathrm{~cd}$ & $38.25 \mathrm{de}$ & $48.63 \mathrm{de}$ & $51.50 \mathrm{~d}$ \\
\hline
\end{tabular}

*Means followed by the same letter (s) within a column are not significantly different according to Tukey's HSD at $p \leq 0.05$. 
Table 4: Effect of NPK fertilizer rates and growing environment on plant height $(\mathrm{cm})$ of pepino melon in trial two

\begin{tabular}{llllllll}
\hline Environment & $\begin{array}{l}\text { Fertilizer } \\
\left(\mathrm{kg} \mathrm{ha}^{-1}\right)\end{array}$ & $30 \mathrm{DAP}$ & 44 DAP & 58 DAP & 72 DAP & 86 DAP & $100 \mathrm{DAP}$ \\
\hline Greenhouse & $0 \mathrm{~kg}$ & $13.28 \mathrm{~d}$ & $16.61 \mathrm{f}$ & $19.93 \mathrm{e}$ & $23.05 \mathrm{e}$ & $28.49 \mathrm{e}$ & $33.00 \mathrm{e}$ \\
& $100 \mathrm{~kg}$ & $22.99 \mathrm{bc}$ & $28.50 \mathrm{~cd}$ & $33.22 \mathrm{c}$ & $36.16 \mathrm{c}$ & $40.39 \mathrm{c}$ & $57.22 \mathrm{bc}$ \\
& $200 \mathrm{~kg}$ & $38.78 \mathrm{a}$ & $44.83 \mathrm{a}$ & $48.34 \mathrm{a}$ & $62.00 \mathrm{a}$ & $70.06 \mathrm{a}$ & $81.33 \mathrm{a}$ \\
& $300 \mathrm{~kg}$ & $25.16 \mathrm{bc}$ & $29.56 \mathrm{c}$ & $33.11 \mathrm{c}$ & $37.22 \mathrm{c}$ & $43.82 \mathrm{bc}$ & $48.94 \mathrm{bc}$ \\
& $400 \mathrm{~kg}$ & $25.67 \mathrm{~b}$ & $29.44 \mathrm{c}$ & $32.17 \mathrm{c}$ & $35.67 \mathrm{c}$ & $43.05 \mathrm{c}$ & $50.34 \mathrm{bc}$ \\
\hline Field & $0 \mathrm{~kg}$ & $18.88 \mathrm{~cd}$ & $20.88 \mathrm{ef}$ & $23.71 \mathrm{de}$ & $25.38 \mathrm{e}$ & $29.59 \mathrm{de}$ & $30.92 \mathrm{e}$ \\
& $100 \mathrm{~kg}$ & $21.67 \mathrm{bc}$ & $23.59 \mathrm{de}$ & $27.75 \mathrm{~cd}$ & $31.84 \mathrm{~cd}$ & $36.17 \mathrm{cde}$ & $37.21 \mathrm{de}$ \\
& $200 \mathrm{~kg}$ & $23.56 \mathrm{bc}$ & $24.84 \mathrm{cde}$ & $29.09 \mathrm{~cd}$ & $31.29 \mathrm{~cd}$ & $40.46 \mathrm{c}$ & $44.04 \mathrm{cde}$ \\
& $300 \mathrm{~kg}$ & $32.82 \mathrm{a}$ & $38.92 \mathrm{~b}$ & $41.06 \mathrm{~b}$ & $51.29 \mathrm{~b}$ & $51.58 \mathrm{~b}$ & $62.00 \mathrm{~b}$ \\
& $400 \mathrm{~kg}$ & $22.38 \mathrm{bc}$ & $24.63 \mathrm{cde}$ & $25.11 \mathrm{de}$ & $33.75 \mathrm{c}$ & $37.46 \mathrm{~cd}$ & $42.17 \mathrm{de}$ \\
\hline
\end{tabular}

*Means followed by the same letter (s) within a column are not significantly different according to Tukey's HSD at $p \leq 0.05$.

Stem diameter: NPK fertilizer rates and growing environment had a significant effect on stem diameter of pepino melon plants. Plants which were grown in the field and supplied with $300 \mathrm{~kg} \mathrm{NPK} \mathrm{ha}{ }^{-1}$ had a significantly high stem diameter at 30 DAP but not significantly different at $p \leq 0.05$ from those grown in the greenhouse and supplied with $200 \mathrm{~kg} \mathrm{NPK} \mathrm{ha}^{-1}$ in trial one. From 44 DAP to 100 DAP plants grown in the greenhouse and supplied with $200 \mathrm{~kg} \mathrm{NPK} \mathrm{ha}^{-1}$ had a significantly high stem diameter at $p \leq 0.05$ though not different from those grown in the field and supplied with $300 \mathrm{~kg} \mathrm{NPK} \mathrm{ha}{ }^{-1}$ in trial one (Table 5). In trial two, plants which were grown in the greenhouse and supplied with $200 \mathrm{~kg} \mathrm{NPK} \mathrm{ha}{ }^{-1}$ had a significantly higher stem diameter at $p \leq 0.05$ though not significantly different from those grown in the field and supplied with $300 \mathrm{~kg} \mathrm{NPK} \mathrm{ha}^{-1}$ from 30 DAP to 86 DAP. At 100 DAP plants grown in the greenhouse and supplied with $200 \mathrm{~kg} \mathrm{NPK} \mathrm{ha} \mathrm{a}^{-1}$ had a stem diameter of $14.01 \mathrm{~mm}$ which was significantly different $p \leq 0.05$ at from those grown in the field and supplied with $300 \mathrm{~kg} \mathrm{NPK} \mathrm{ha}^{-1}$ with a stem diameter of $11.71 \mathrm{~mm}$ (Table 6).

Table 5: Effect of NPK fertilizer rates and growing environment on stem diameter( $\mathrm{mm})$ of pepino melon in trial one

\begin{tabular}{llllllll}
\hline Environment & $\begin{array}{l}\text { Fertilizer } \\
\left(\mathrm{kg} \mathrm{ha}^{-1}\right)\end{array}$ & $30 \mathrm{DAP}$ & 44 DAP & 58 DAP & $72 \mathrm{DAP}$ & 86 DAP & $100 \mathrm{DAP}$ \\
\hline Greenhouse & $0 \mathrm{~kg}$ & $4.91 \mathrm{c}$ & $5.91 \mathrm{de}$ & $7.33 \mathrm{~d}$ & $4.84 \mathrm{~d}$ & $5.51 \mathrm{c}$ & $6.92 \mathrm{~d}$ \\
& $100 \mathrm{~kg}$ & $5.72 \mathrm{bc}$ & $8.37 \mathrm{bc}$ & $9.35 \mathrm{c}$ & $8.02 \mathrm{bcd}$ & $9.03 \mathrm{bc}$ & $9.83 \mathrm{c}$ \\
& $200 \mathrm{~kg}$ & $8.56 \mathrm{ab}$ & $9.96 \mathrm{a}$ & $12.55 \mathrm{a}$ & $14.30 \mathrm{a}$ & $15.63 \mathrm{a}$ & $13.11 \mathrm{ab}$ \\
& $300 \mathrm{~kg}$ & $4.89 \mathrm{c}$ & $8.21 \mathrm{bc}$ & $9.64 \mathrm{bc}$ & $6.09 \mathrm{~cd}$ & $6.99 \mathrm{bc}$ & $9.75 \mathrm{c}$ \\
& $400 \mathrm{~kg}$ & $4.31 \mathrm{c}$ & $7.08 \mathrm{~cd}$ & $9.91 \mathrm{bc}$ & $5.82 \mathrm{~cd}$ & $6.49 \mathrm{bc}$ & $9.37 \mathrm{~cd}$ \\
\hline Field & $0 \mathrm{~kg}$ & $4.52 \mathrm{c}$ & $4.08 \mathrm{f}$ & $5.21 \mathrm{e}$ & $7.93 \mathrm{bcd}$ & $5.51 \mathrm{c}$ & $10.40 \mathrm{c}$ \\
& $100 \mathrm{~kg}$ & $3.94 \mathrm{c}$ & $4.79 \mathrm{ef}$ & $5.85 \mathrm{de}$ & $8.78 \mathrm{bc}$ & $8.62 \mathrm{bc}$ & $9.99 \mathrm{c}$ \\
& $200 \mathrm{~kg}$ & $4.88 \mathrm{c}$ & $4.51 \mathrm{ef}$ & $5.64 \mathrm{de}$ & $8.29 \mathrm{bcd}$ & $9.87 \mathrm{~b}$ & $10.70 \mathrm{bc}$ \\
& $300 \mathrm{~kg}$ & $9.05 \mathrm{a}$ & $9.41 \mathrm{ab}$ & $11.34 \mathrm{ab}$ & $11.09 \mathrm{ab}$ & $14.32 \mathrm{a}$ & $15.32 \mathrm{a}$ \\
& $400 \mathrm{~kg}$ & $4.41 \mathrm{c}$ & $4.69 \mathrm{ef}$ & $6.32 \mathrm{de}$ & $8.59 \mathrm{bcd}$ & $9.30 \mathrm{~b}$ & $10.64 \mathrm{bc}$ \\
\hline
\end{tabular}

*Means followed by the same letter (s) within a column are not significantly different according to Tukey's HSD at $p \leq 0.05$. 
Table 6: Effect of NPK fertilizer rates and growing environment on stem diameter $(\mathrm{mm})$ of pepino melon in trial two

\begin{tabular}{llllllll}
\hline Environment & $\begin{array}{l}\text { Fertilizer } \\
\left(\mathrm{kg} \mathrm{ha}^{-1}\right)\end{array}$ & $30 \mathrm{DAP}$ & 44 DAP & 58 DAP & $72 \mathrm{DAP}$ & $86 \mathrm{DAP}$ & $100 \mathrm{DAP}$ \\
\hline Greenhouse & $0 \mathrm{~kg}$ & $3.38 \mathrm{~d}$ & $4.11 \mathrm{c}$ & $5.30 \mathrm{c}$ & $6.64 \mathrm{c}$ & $8.25 \mathrm{~b}$ & $8.94 \mathrm{c}$ \\
& $100 \mathrm{~kg}$ & $4.29 \mathrm{~cd}$ & $4.97 \mathrm{bc}$ & $6.66 \mathrm{bc}$ & $7.73 \mathrm{c}$ & $8.58 \mathrm{~b}$ & $9.50 \mathrm{c}$ \\
& $200 \mathrm{~kg}$ & $5.91 \mathrm{a}$ & $7.61 \mathrm{a}$ & $9.05 \mathrm{a}$ & $10.85 \mathrm{a}$ & $11.93 \mathrm{a}$ & $14.01 \mathrm{a}$ \\
& $300 \mathrm{~kg}$ & $4.49 \mathrm{bc}$ & $5.30 \mathrm{bc}$ & $6.51 \mathrm{bc}$ & $7.33 \mathrm{c}$ & $8.31 \mathrm{~b}$ & $8.99 \mathrm{c}$ \\
& $400 \mathrm{~kg}$ & $4.57 \mathrm{bc}$ & $5.19 \mathrm{bc}$ & $6.74 \mathrm{bc}$ & $7.86 \mathrm{bc}$ & $8.25 \mathrm{~b}$ & $9.12 \mathrm{c}$ \\
\hline Field & $0 \mathrm{~kg}$ & $1.32 \mathrm{e}$ & $1.77 \mathrm{~d}$ & $2.23 \mathrm{~d}$ & $2.83 \mathrm{~d}$ & $3.43 \mathrm{~d}$ & $3.21 \mathrm{f}$ \\
& $100 \mathrm{~kg}$ & $1.72 \mathrm{e}$ & $2.07 \mathrm{~d}$ & $2.36 \mathrm{~d}$ & $3.04 \mathrm{~d}$ & $4.26 \mathrm{~cd}$ & $4.48 \mathrm{ef}$ \\
& $200 \mathrm{~kg}$ & $2.28 \mathrm{e}$ & $2.02 \mathrm{~d}$ & $2.76 \mathrm{~d}$ & $3.15 \mathrm{~d}$ & $4.79 \mathrm{~cd}$ & $5.76 \mathrm{de}$ \\
& $300 \mathrm{~kg}$ & $5.37 \mathrm{ab}$ & $6.20 \mathrm{~b}$ & $7.81 \mathrm{ab}$ & $9.45 \mathrm{ab}$ & $11.00 \mathrm{a}$ & $11.71 \mathrm{~b}$ \\
& $400 \mathrm{~kg}$ & $1.71 \mathrm{e}$ & $2.37 \mathrm{~d}$ & $2.98 \mathrm{~d}$ & $3.47 \mathrm{~d}$ & $5.45 \mathrm{c}$ & $6.06 \mathrm{~d}$ \\
\hline
\end{tabular}

* Means followed by the same letter (s) within a column are not significantly different according to Tukey's HSD at $p \leq 0.05$.

Number of leaves per bush before flowering: NPK fertilizer rates and growing environment had a significant effect $p \leq 0.05$ at on number of leaves. In both trials plants which were supplied with 400 $\mathrm{kg} \mathrm{NPK} \mathrm{ha}{ }^{-1}$ whether grown in the field or greenhouse had the highest number of leaves per bush just before flowering compared to the control in both environments. In trial one, plants supplied with 400 $\mathrm{kg}$ NPK ha ${ }^{-1}$ had 128.79 and 126.67 leaves per bush in the greenhouse and field environments respectively (Fig. 1). Plants which were not supplied with fertilizer had the lowest number of leaves in both environments and trials. It was observed that as the fertilizer rate increased the number of leaves also increased in both environments and trials.

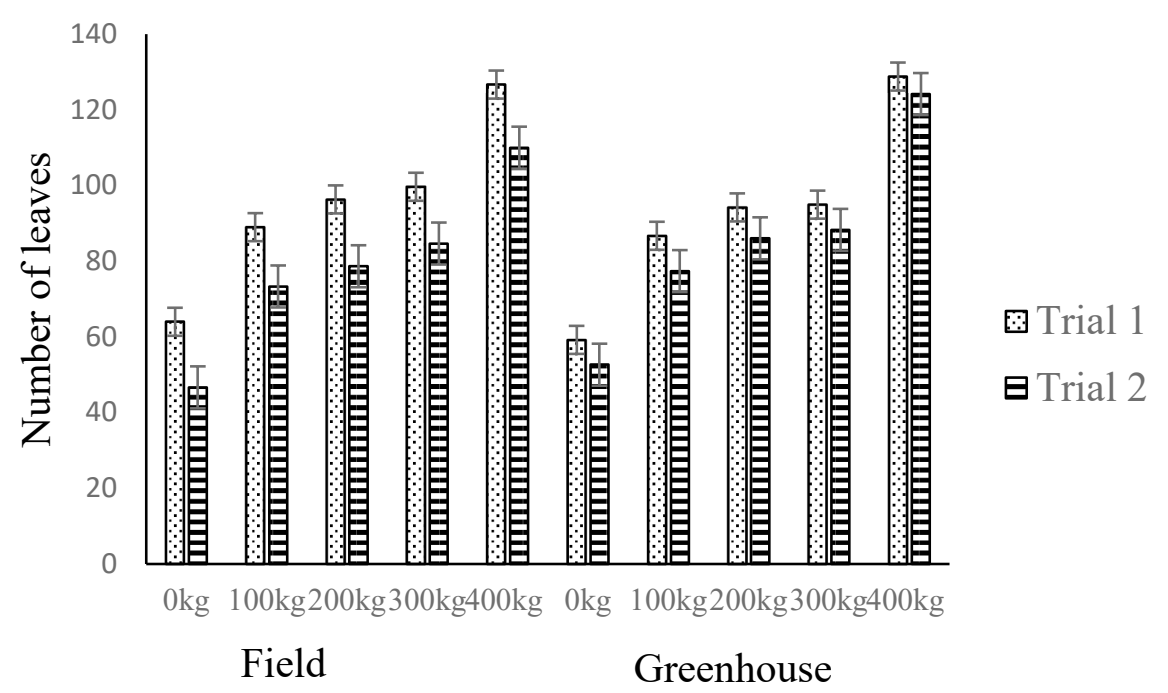

Figure 1: Effect of NPK fertilizer rates and growing environment on number of leaves of pepino melon in trial 1 and 2

Number of branches: NPK fertilizer rates and growing environment had a significant effect at $p \leq$ 0.05 on the number of primary branches. In trial one plants supplied with $200 \mathrm{~kg} \mathrm{NPK} \mathrm{ha}^{-1}$ and grown in the greenhouse had 23.05 branches while those supplied with $300 \mathrm{~kg} \mathrm{NPK} \mathrm{ha}^{-1}$ and grown in the field had 19.35 branches and were not significantly different at $p \leq 0.05$. Control recorded the lowest number of branches with 8.99 and 7.13 branches for greenhouse and field grown pepino melons respectively. However, plants supplied with $300 \mathrm{~kg}$ NPK and grown in the field were not significantly different from greenhouse plants supplied with 400 and $300 \mathrm{~kg} \mathrm{NPK} \mathrm{ha}^{-1}$. In trial two, field grown plants supplied with $300 \mathrm{~kg} \mathrm{NPK} \mathrm{ha}^{-1}$ had 18.46 branches while greenhouse grown plants supplied with $200 \mathrm{~kg} \mathrm{NPK} \mathrm{ha}{ }^{-1}$ had 15.03 branches and they were not significantly different at $p \leq 0.05$. 
Greenhouse grown plants that received $200 \mathrm{~kg} \mathrm{NPK} \mathrm{ha}^{-1}$ were not significantly different at $p \leq 0.05$ from field grown plants that received 400,100 and $200 \mathrm{~kg} \mathrm{NPK} \mathrm{ha}^{-1}$ and greenhouse grown plants that received 100, 300 and $400 \mathrm{~kg} \mathrm{NPK} \mathrm{ha}^{-1}$ (Fig. 2). The control plants had the lowest number of branches with 9.13 and 7.06 branches for field and greenhouse grown pepino plants respectively. Generally, it was observed that plants had higher number of branches in trial one compared to trial two.

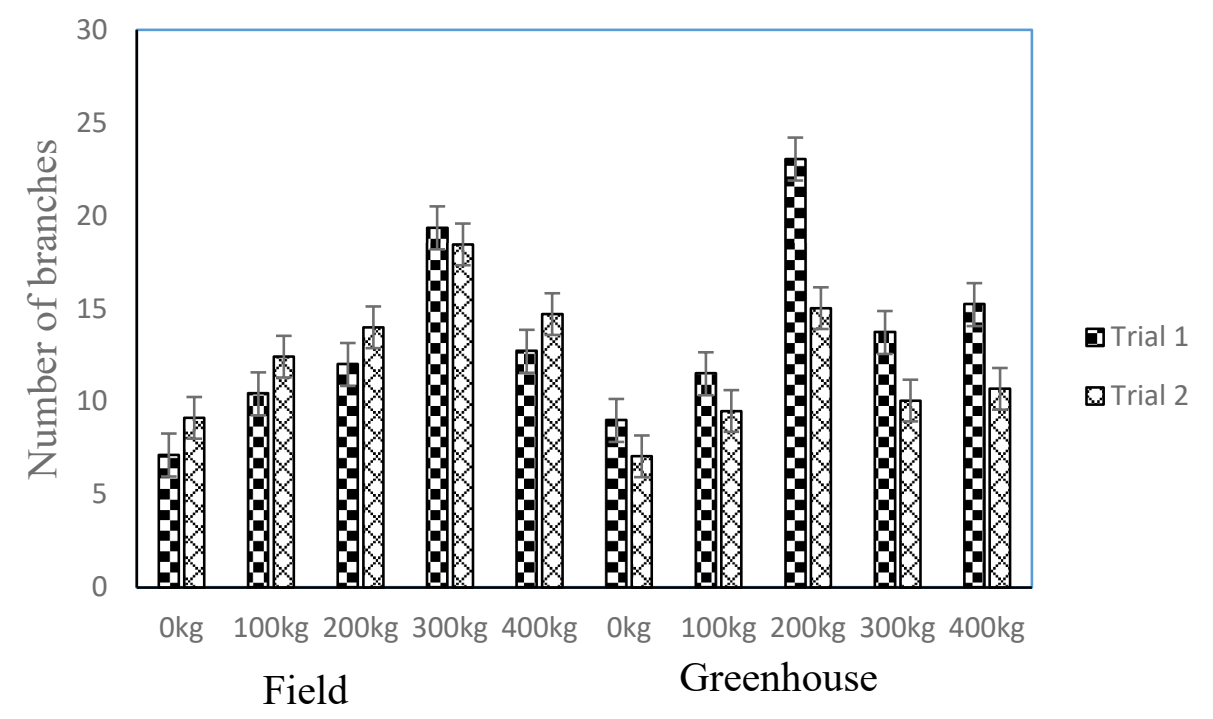

Figure 2: Effect of NPK fertilizer rates and growing environment on number of branches of pepino melon in trial 1 and 2

Days to 50\% flowering: NPK fertilizer rates and growing environment had a significant effect at $p$ $\leq 0.05$ on days to $50 \%$ flowering. Plants which were supplied with NPK fertilizer took longer to flower compared to the control which took the shortest time to flower in both environments and trials. In trial one, control plants grown in the field took an average of 33 days to flower while those grown in the greenhouse took an average of 31 days to flower. In trial one plants which were supplied with $400 \mathrm{~kg} \mathrm{NPK} \mathrm{ha}{ }^{-1}$ took 63 and 60 days to flower in the field and greenhouse respectively. In trial two, plants supplied with $400 \mathrm{~kg} \mathrm{NPK} \mathrm{ha}^{-1}$ took 65 and 60 days in the field and greenhouse respectively (Fig. 3). Plants supplied with the other fertilizer rates took between 35 to 45 days to flower. Generally, plants in the greenhouse took a shorter time to flower compared to those grown in the field.

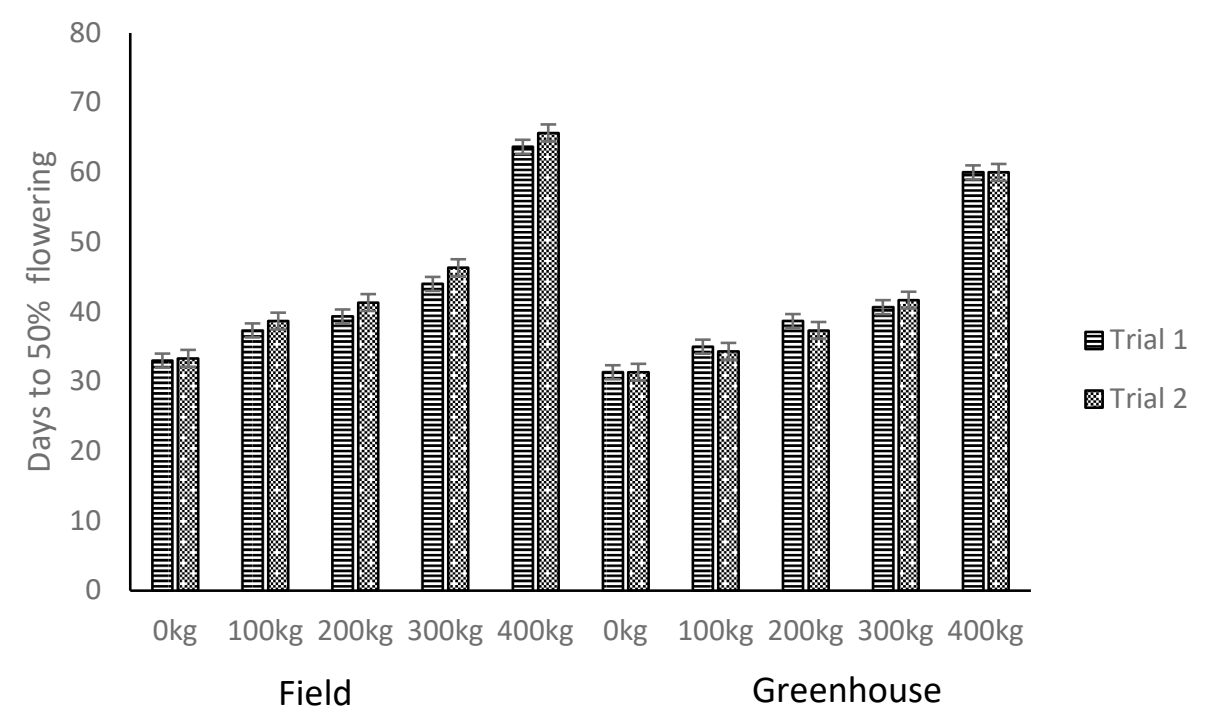

Figure 3: Effect of NPK fertilizer rates and growing environment on number of days to $50 \%$ flowering of pepino melon in trial 1 and 2 
Fruit weight: NPK fertilizer rates and growing environment had a significant effect at $p \leq 0.05$ on fruit weight of pepino melon. Field grown plants supplied with $300 \mathrm{~kg} \mathrm{NPK} \mathrm{ha}^{-1}$ had the highest fruit weight of $380.23 \mathrm{~g}$ and $361.46 \mathrm{~g}$ in trials one and two respectively. In trial one, pepino plants which received $0 \mathrm{~kg} \mathrm{NPK} \mathrm{ha}{ }^{-1}$ had a fruit weight of $137.04 \mathrm{~g}$ and $68.53 \mathrm{~g}$ in the field and greenhouse respectively (Fig. 4). Generally, field grown pepino melons had a higher fruit weight compared to greenhouse grown pepino plants. It was also observed that as the NPK fertilizer rates increased the fruit weight also increased up to $300 \mathrm{~kg} \mathrm{NPK} \mathrm{ha}^{-1}$ for field grown plants and $200 \mathrm{~kg} \mathrm{NPK} \mathrm{ha}^{-1}$ for greenhouse grown pepino melons. Increasing NPK fertilizer rates above $300 \mathrm{~kg} \mathrm{NPK} \mathrm{ha}^{-1}$ for field grown plants and $200 \mathrm{~kg} \mathrm{NPK} \mathrm{ha}^{-1}$ for greenhouse grown did not lead to a significant increase in fruit weight.

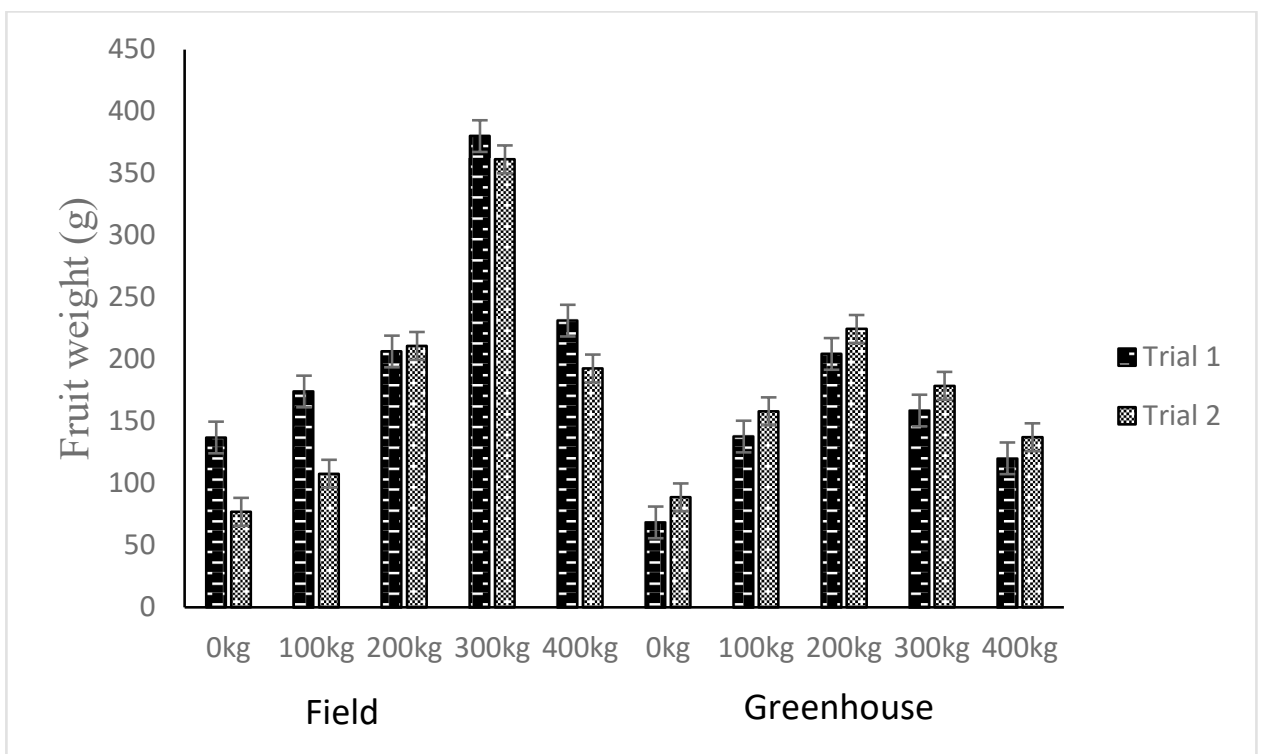

Figure 4: Effect of NPK fertilizer rates and growing environment on fruit weight of pepino melon in trial 1 and 2

Total yield: NPK fertilizer rates and growing environment had a significant effect at $p \leq 0.05$ on total yield of pepino melon. Increasing rates of NPK fertilizer led to an increase in the total yield of pepino melon in both growing environments (Fig. 5). However, it was noted that increasing the rate above $300 \mathrm{~kg} \mathrm{NPK} \mathrm{ha}{ }^{-1}$ for field grown plants and $200 \mathrm{~kg} \mathrm{NPK} \mathrm{ha}^{-1}$ for the greenhouse grown pepino plants led to an insignificant increase or decrease in yield. The control (no fertilizer) recorded the lowest total yield in both environments and trials. Field grown pepino melons that were supplied with 300 $\mathrm{kg} \mathrm{NPK} \mathrm{ha} \mathrm{H}^{-1}$ had the highest yield of $1102.48 \mathrm{~kg} \mathrm{ha}^{-1}$ and $1060.55 \mathrm{~kg} \mathrm{ha}^{-1}$ in trial one and two respectively (Fig. 5). Greenhouse grown plants supplied with $200 \mathrm{~kg} \mathrm{NPK} \mathrm{ha}^{-1}$ had a total yield of $782.64 \mathrm{~kg} \mathrm{ha}^{-1}$ and $648.8 \mathrm{~kg} \mathrm{ha}^{-1}$ in trial one and two respectively. In trial one, plants not supplied with fertilizer (control) had a total yield of $411.22 \mathrm{~kg} \mathrm{ha}^{-1}$ and $211.36 \mathrm{~kg} \mathrm{ha}^{-1}$ in the field and greenhouse respectively. In trial two, the control recorded $209.4 \mathrm{~kg} \mathrm{ha}^{-1}$ and $212.7 \mathrm{~kg} \mathrm{ha}^{-1}$ in the field and greenhouse respectively. Generally, it was observed that the yield was higher in the field grown compared to the greenhouse grown pepino melons. It was also observed that the total yield was higher in trial one compared to trial two. 


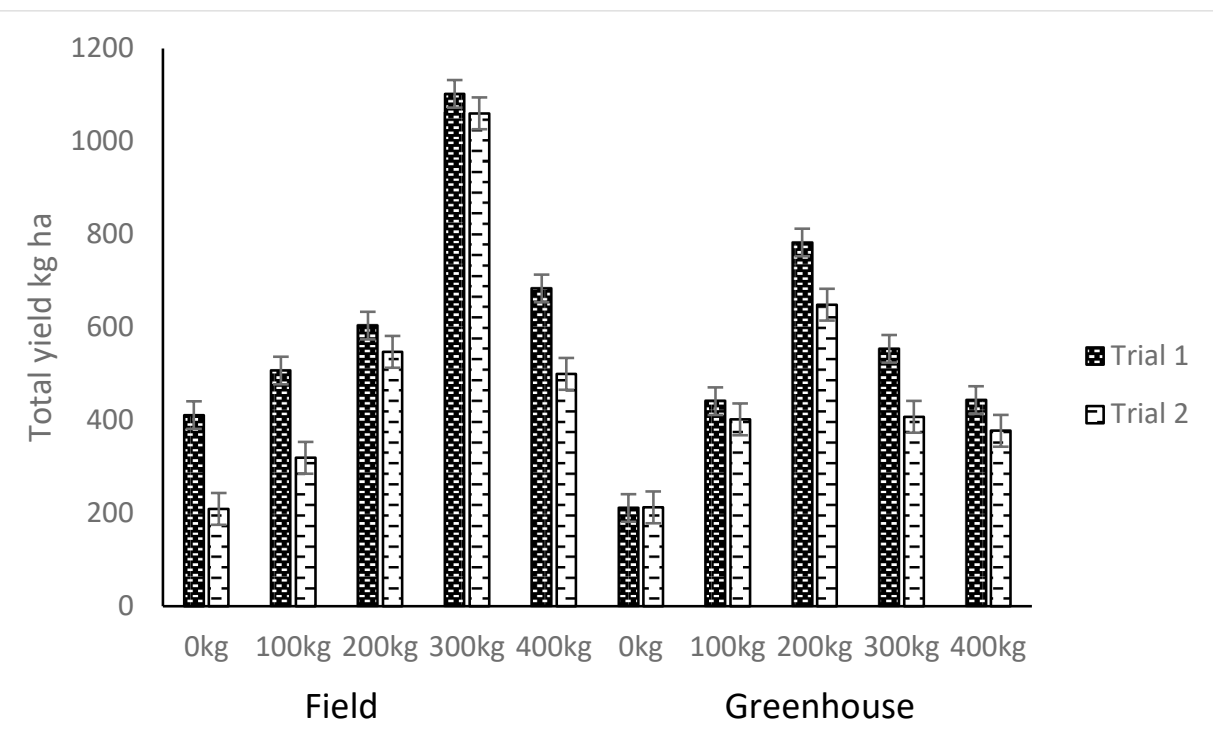

Figure 5: Effect of NPK fertilizer rates and growing environment on total yield of pepino melon in trial 1 and 2

\section{Discussion}

NPK fertilizer rates and growing environment has a significant effect on height of pepino melon plants. Similar results were reported by [18] in which capsicum plants that received NPK 150:120:60 kg ha ${ }^{-1}$ fertilizer resulted to increased plant height of $60.10 \mathrm{~cm}$ compared to other NPK fertilizer rates and the control. Similarly, [19] reported that bell pepper plants that were grown in the polyhouse were taller than those grown in the open field. There was a significant increase in plant height in the plots that were supplied with $200 \mathrm{~kg} \mathrm{NPK} \mathrm{ha}^{-1}$ in the greenhouse and $300 \mathrm{~kg} \mathrm{NPK} \mathrm{ha}^{-1}$ in the field compared to the control. The higher response in pepino melon growth in the greenhouse might be due to availability of essential elements from the NPK fertilizer. Plant height is very important for determining growth of crops [20]. The increase in plant height of pepino melon plants supplied with NPK fertilizer could be due to the release of nutrients from the fertilizer and this led to an increase in photosynthesis [21]. Increased rates of NPK fertilizer resulted in higher growth including plant height in both growing environments. Optimum plant height is positively correlated with plant productivity [22]. On the other hand, the low plant height recorded in the control in both environments was due to lack of nutrients which led to reduced growth. Increasing NPK fertilizer rates above $200 \mathrm{~kg} \mathrm{NPK} \mathrm{ha}^{-1}$ in the greenhouse and $300 \mathrm{~kg} \mathrm{NPK} \mathrm{ha}^{-1}$ in the field did not result into an increase of plant height. This could be due to luxurious consumption of nutrients by the crops leading to no increase in growth.

NPK fertilizer rates and growing environment had a significant effect on stem diameter of pepino melon plants. The average stem diameter of $4.08 \mathrm{~cm}$ in capsicum plants which were supplied with NPK 150:120:60 $\mathrm{kg} \mathrm{ha}^{-1}$ compared to the other NPK fertilizer rates and the control [18]. Stem diameter is one of the most important sites for the storage of food materials from photosynthesis and can be influenced by the nutrients present in the soil [23]. Plants which were grown in the greenhouse had a larger stem diameter compared to those grown in the open field. This may be due to increased photosynthesis and respiration due to the favorable micro climatic conditions in the greenhouse [24].

NPK fertilizer treatments significantly influenced the vegetative performance of pepino melon plants. Plants which were supplied with $400 \mathrm{~kg} \mathrm{NPK} \mathrm{ha}^{-1}$ had the highest number of leaves in both environments and this could be due to the high amount of nitrogen in the fertilizer. Nitrogen is a component of the chlorophyll molecule and promotes vegetative growth which in turn helps in flowering and fruit set. Similar results were reported by Babatunde et al., [25] where application of NPK fertilizer (15:15:15) had a significant effect on number of leaves of tomato plants. Nafiu et al., [26] also reported that application of $300 \mathrm{~kg} \mathrm{NPK} \mathrm{ha}^{-1}$ on okra led to increased number of leaves compared to the control and the other treatments, in this experiment $300 \mathrm{~kg} \mathrm{NPK} \mathrm{ha}^{-1}$ was the highest 
fertilizer treatment. Furthermore, Okonwu and Monsah [27] reported that application of $350 \mathrm{~kg}$ NPK $\mathrm{ha}^{-1}$ led to increased number of leaves of pumpkin. On the contrary, Gloria et al., [28] reported that application of NPK fertilizer rates did not have a significant effect on the number of leaves of okra. The increase in number of leaves in our study can be attributed to nitrogen supply in the fertilizer applied and the fact that nutrient availability especially nitrogen influenced plant vegetative development which is in agreement with Babatunde et al., [25]. The low number of leaves in the control treatments could be due to low levels of nitrogen.

Number of branches was greatly influenced by the growing environment and NPK fertilizer application. Naik et al., [24] also reported increased number of branches of tomato plants grown in the greenhouse. Similarly, Lego et al., [18] reported that application of NPK 150:120:60 kg ha-1 led to an increase in the number of branches of capsicum (Capsicum annuum L.) cv Asha. The significant difference observed in the number of branches can be due to the fact that the NPK fertilizer applied to the soil was readily available in a form that is readily absorbed by plant roots and thereby resulting to a significant increase in the morphological growth of the plants [29]. The number of branches is positively correlated to yield. On the contrary, Nafiu et al., [26] reported that an increase in the number of branches did not lead to increased okra fruit production as expected. This might be due to the fact that other shoot characteristics were favored in growth at the expense of fruit production. Nafiu et al., [26] reported that okra plants that received an application of $300 \mathrm{~kg} \mathrm{NPK} \mathrm{ha}^{-1}$ had the highest number of primary branches.

Statistically significant results were observed for days taken to flowering. Plants which were not supplied with any fertilizer (control) took the shortest time to flower while those supplied with the highest fertilizer rate $400 \mathrm{~kg} \mathrm{NPK} \mathrm{ha}^{-1}$ took the longest time to flower. Kumar et al., [30] reported that increasing levels of NPK delayed flowering of tomato plants. On the contrary, Imran et al., [31] reported that cucumber plants which were not supplied with any fertilizer took the longest time (38 days) to flower compared to application of $1000 \mathrm{~g}$ fertigation $^{-1}$. In this study it was observed that greenhouse plants flowered earlier compared to field grown plants. Similarly, Nkansah et al., [32] reported that sweet pepper plants grown in the greenhouse flowered earlier than those grown in the open field. This could be due to the micro climate in the greenhouse. Pepino plants supplied with 400 $\mathrm{kg} \mathrm{NPK} \mathrm{ha}{ }^{-1}$ took the longest time to flower in the field and greenhouse. This was attributed to excessive nitrogen which favored vegetative growth at the expense of flower development. The short time taken by pepino plants which were not supplied with NPK fertilizer (control) to attain 50\% flowering in both environments could be due to lack of essential nutrients which are needed by plants for growth.

There was a significant effect of NPK fertilizer rates and growing environment on fruit weight of pepino melon. Field grown plants supplied with $300 \mathrm{~kg} \mathrm{NPK} \mathrm{ha}^{-1}$ had the highest fruit weight in both trials. However, it was noted that application of NPK fertilizer beyond $300 \mathrm{~kg} \mathrm{NPK} \mathrm{ha}^{-1}$ did not significantly increase fruit weight of pepino plants grown in the field. Results of this study for both greenhouse and field grown pepino melons are in agreement with those of Oloyede et al., [33] who found that increasing NPK fertilizer rate led to an increase in fruit weight of pumpkin up to a point beyond which there was no significant increase pumpkin fruit weight. Temperature plays a very important role in growth and development of fruits in most fruit vegetables [34]. High air temperature encourages early fruit production compared to vegetative growth and this might eventually lead to less fruit production [35]. Low air temperatures lead to increased number of flowers, late ripening and large fruits [36]. This might be the reason why field grown fruits had a higher fruit weight compared to greenhouse grown fruits. Papadopoulus and Hao [37] reported that day temperatures of $19^{\circ} \mathrm{C}$ led to early yields, total yield and the best fruit weight for greenhouse grown tomatoes. Therefore, if the temperature is above $19^{\circ} \mathrm{C}$ fruit size will be reduced and this is due to decreased pollination and fertilization at high temperatures [38]. The temperature in the greenhouse were above $19^{\circ} \mathrm{C}$ most of the months and this may be the cause for low fruit weight of greenhouse grown pepino melons. Increase in temperature leads to a decrease in fruit weight and this could be due to reduced translocation of sugars [39]. Results of this study are in agreement with those of Ahumada and Cantwell [40] who reported that the fruit weight of pepino melon ranged from 100 to $500 \mathrm{~g}$. On the 
contrary, lower fruit weight of $268 \mathrm{~g}, 80-250 \mathrm{~g}$ and $181-330 \mathrm{~g}$ of pepino melon have been reported [41-43]. Similarly, Martinetti and Paganini [44] reported that increased fertilizer rates led to an increase in fruit weight up to a point beyond which there was no significant increase in fruit weight. The low fruit weight obtained following application of $400 \mathrm{~kg} \mathrm{NPK} \mathrm{ha}^{-1}$ could be attributed to excess nitrogen which leads to reduced plant growth, small leaves, stunted root systems and in severe cases death [45].

NPK fertilizer rates and growing environment had a significant effect on total yield of pepino melon. Field grown pepino melon plants had the highest yield compared to greenhouse grown plants. Application of $300 \mathrm{~kg} \mathrm{NPK} \mathrm{ha}{ }^{-1}$ for field grown pepino melons gave the highest total yield in both trials. Similar trend of results was obtained by Gloria et al., [28] who reported that application of NPK fertilizer increased the yield of okra plants. In the study, okra plants which were supplied with 13g of NPK had the highest yield and control had the lowest yield. The results of our study are in harmony with the findings of Omotoso and Shitu [46] who concluded that increasing NPK fertilizer rates led to an increase in the yield of okra plants. In this study field grown pepino plants had a high total yield compared to greenhouse grown plants. On the contrary, Nkansah et al., [32] reported high yield for greenhouse grown sweet pepper compared to open field grown sweet pepper plants. In a study by Cavusoglu et al., [41] the yield of pepino melon was found to be $3.68 \mathrm{tha}^{-1}$ to $14.03 \mathrm{tha}^{-1}$. This was higher than the yield recorded in this study, however, Cavusoglu et al., [41] reported that the yield of pepino melon depends on climatic conditions. In this study, the low yield recorded in the greenhouse might be due to increased flower abortion as compared to field where flower abortion was minimal. Flower abortion occurred in the greenhouse because of high temperatures. In trial one the average temperature in the greenhouse ranged from $21^{\circ} \mathrm{C}$ to $35.8^{\circ} \mathrm{C}$, whereas in trial two it ranged from $18.5^{\circ} \mathrm{C}$ to $35.3^{\circ} \mathrm{C}$ (Table 2). It was noted that flower abortion occurred when the temperature in the greenhouse was above $30^{\circ} \mathrm{C}$. When the temperatures are above $30^{\circ} \mathrm{C}$, this contributed to poor conditions for pepino melon fruit formation [47]. Temperature is vital for fruit set in most solanaceous vegetables [48]. In tomato, a mean daily temperature of $29^{\circ} \mathrm{C}$ leads to a decrease in fruit number and fruit weight [49]. This could be due to the fact that the reproductive organs of most solanaceous vegetables are highly sensitive to high temperature compared to the vegetative organs [50]. Furthermore, temperatures above $23^{\circ} \mathrm{C}$ affects one or more processes involved in successful fertilization [51]. Metabolic processes in tomato are favored by temperatures of between $25-30^{\circ} \mathrm{C}$ while fruit set requires a mean daily temperature of $21-24^{\circ} \mathrm{C}$ [52]. The reduced yield in the greenhouse grown pepino fruits could be due to high temperatures which could have led to impaired pollen germination, pollen tube growth and fertilization resulting to flower abortion and hence reduced fruit set [53]. High temperature in tomato plants led to a decrease in sucrose uptake to the developing flower buds and this causes flower abortion and this may also have been the case in greenhouse grown pepino melons [54]. Additionally, high day time temperatures in pepper lead to a decrease in the activity of acid invertase in the developing flower buds and this explains the in ability of reproductive organs to take up assimilates [55]. Apart from reducing up take of carbohydrates in the developing flower buds, high temperature also leads to increased production of ethylene by the flowers and this will also lead to flower abortion but this will depend on the cultivar [56]. Under high temperatures conditions low fruit set is caused by reduced pollen viability [57]. Decrease in pollen viability may be due to changes which occur during the development of the anthers [52]. During the tetrads stage, high temperature affects the structure and function of the tapetum which plays a vital role of providing nutrients to the pollen mother cells and regulating the release of pollen grains [52]. Fruit set in tomato was reduced under high temperatures due to reduced release of pollen grains [58]. The malfunctioning of the tapetum causes pollen sterility and this have led to the low fruit set leading to low yields for greenhouse grown plants. High temperature during the tetrads stage in tomatoes causes enlargement of the tapetal cells and this leads to pollen sterility [59]. In summary the results of this study are in agreement with the findings of [49], [57-59] and also with another study which was carried out in a glasshouse in Turkey, where it was observed that when the temperature was above $25^{\circ} \mathrm{C}$ flower formation and fruit set of pepino melon was negatively affected [41]. The field temperature during this study ranged from $19.7^{\circ} \mathrm{C}$ to $22.8^{\circ} \mathrm{C}$ in trial one and $18.9^{\circ} \mathrm{C}$ to $20.5^{\circ} \mathrm{C}$ in trial two (Table 2), thus 
reduced flower abortion and hence the high yield recorded in the field grown pepino melons in the two trials. The low temperature recorded in the field might have led to an increase in the number of floral organs possibly due to the initiation of a high number of flower primordia [60]. This might explain the high total yield recorded for the field grown pepino melons because high yield depends on profusion of flowering, successful pollination and fertilization.

\section{Conclusions}

Growth parameters were favored by growing pepino melon in the greenhouse. However, yield in the greenhouse was not as high as it was in the field. Application of $300 \mathrm{~kg} \mathrm{NPK} \mathrm{ha}^{-1}$ and growing of pepino melons in the field gave the highest fruit weight and yield. Application of NPK fertilizer beyond $300 \mathrm{~kg} \mathrm{ha}^{-1}$ for field grown pepino melons is uneconomical as it does not result to a significant increase in yield. On the other hand, control recorded the lowest growth, fruit weight and yield in both field and greenhouse.

It is therefore recommended that field grown pepino melons should be supplied with $300 \mathrm{~kg} \mathrm{NPK} \mathrm{ha}$

${ }^{1}$ for optimum fruit weight and yield at the location where this experiment was conducted. Yield may vary depending on climatic conditions, soil, environmental conditions and plant nutrition.

\section{Conflict of Interest}

Authors have declared that they do not have any conflict of interest regarding this manuscript.

\section{Acknowledgments}

The authors would like to express their sincere appreciation and thanks to Centre of Excellence in Sustainable Agriculture and Agribusiness Management (CESAAM) for the financial support of this research. We thank Egerton University for hosting this research.

\section{References}

[1] G. Sudha, et al., Antioxidant activity of ripe pepino fruit (Solanum muricatum Aiton). Int. J. Pharmaceutical Sci. 3 (2011) 257-261.

[2] S. Huyskens-Keil, et al., Postharvest quality of pepino (Solanum muricatum Ait.) fruit in controlled atmosphere storage, J. Food Eng. 77 (2006) 628-634.

[3] C. Munoz, et al., Genetic variability in Chilean pepino (Solanum muricatum Aiton) fruit, Chilean J. Agricul. Res. 74 (2014) 143-147.

[4] D. Kahuro, Pepino melon cost analysis and returns. Retrieved on $28^{\text {th }}$ March, 2020 from https://dicksonkahuro.wordpress.com, 2017.

[5] D. Martinez-Romero, M. Serrano, D. Valero, Physiological changes in pepino (Solanum muricatum Ait.) fruit stored at chilling and non-chilling temperatures, Postharvest Biol. Technol. 30 (2003) 117-86.

[6] L. Diaz, Industrializaci 'on y aprovechamiento de productos y sub-productos derivados de materias primas agropecuarias de la regi 'on de Coquimbo. 1st ed. Santiago: LOM ediciones Ltda, 2006.

[7] M. M. Oczan, O. Arslan, Bioactive and some nutritional characteristics of pepino (Solanum muricatum Aiton) fruit, J. Agricul. Sci. Technol. 1 (2011) 133-137.

[8] A. Shaheen, et al., Integrated soil management in eroded land augments the crop yield and wateruse efficiency, Acta Agricul. Scie. Soil and Plant Sci. 60(3) (2010) 274 - 282.

[9] W. Liu, et al., Influence of nitrogen on the primary and secondary metabolism and synthesis of flavonoids in Chrysanthemum morifolium ramat, J. Plant Nutri. 33(2) (2010) 240-254.

[10] S. E. Obalum, et al., Soil Degradation-Induced Decline in Productivity of Sub-Saharan African Soils: The Prospects of Looking Downwards the Lowlands with the Sawah Ecotechnology, Appl. Environ. Soil Sci. 2012: 1-10. 
[11] E. O. Uyovbisere, V. O. Chude, A. Bationo, Promising nutrient ratios in the fertilizer formulations for optimal performance of maize in the Nigerian Savanna. The need for a review of current recommendations, Nigerian J. Soil Res. 1 (2000) 29-34.

[12] R. Jaetzold, H. Schmidt, Farm management handbook of Kenya, Natural conditions and farm management information, Ministry of Agriculture Kenya, 2006.

[13] FAO, Neglected Crops: 1492 from a different perspective, FAO plant production and protection series, No. 26 ISBN 92-5-103217-3, 1994.

[14] J. R. Okalebo, K. W. Gathua, P. L. Woomer, Laboratory methods of soil and water analysis: A working manual, Second edition, 2002, 128 pp.

[15] Z. Cong, H. Lu, G. Ni, A simplified dynamic method for field capacity estimation and its parameter analysis, Water Sci. Eng. 7(4) (2014) 351-362.

[16] T. K. Lim, Fruits. In T. K. Lim (Ed.), Edible Medicinal and Non-medicinal plants, Retrieved from http://www.springer.com>book p. 390-394, 2013.

[17] SAS Institute. Step by Step Basic Statistics Using SAS; Student Guide; Version 9.1 Cary, SAS Institute Inc., North Carolina, 2005, USA. 40 pp.

[18] M. Lego, D. Singh, S. Tsanglao, Effect of different levels of NPK on growth, yield and economic of capsicum (Capsicum annuum L.) CV Asha under shade net house cultivation, Internat. J. Agric. Sci. Res. 6(4) (2016) 5-8.

[19] M. S. Dhaliwal et al., Growth and yield of bell pepper as influenced by growing environment, mulch and planting date, J. Crop Improv. 31(6) (2017) 830-846.

[20] K. O. Sanni, Effect of compost, cow dung and NPK 15-15-15 fertilizer on growth and yield of Amaranth (Amaranthus hydridus), Internat. J. Advances in Scientific Res. 2(3) (2016) 76-82.

[21] H. Iqtidar, K. M. Ayyaz, K. E. Ahmad, Bread Wheat Varieties as Influenced by Different Nitrogen Levels, J. Zhejiang University Sci. 7(1) (2006) 70-78.

[22] I. N. Saeed, K. Abbasi, M. Kazim, Response of maize (Zea nmays) to nitrogen and phosphorus fertilization under agro-climatic condition of Rawalokot Azad Jammu and Kashmir, Pakistan J. Biol. Sci. 4 (2001) 53-55.

[23] A. K. G. Godia, Evaluation of some introduced fresh market tomato (Solanum lycopersicum L.) for genetic variability and adaptability in Ghana using morphological and molecular markers, MSc. Thesis, Kwame Nkurumah University of Science and Technology, Kumasi, Ghana, 2014.

[24] M. R. Naik, C. H. Ruth, C. H. Chinnabbai, Growth, flowering and yield response of tomato varieties under polyhouse conditions, Internat. J. Pure Appl. Biosci. 6(1) (2018) 1303-1307.

[25] K. M. Babatunde, et al., Effects of individual and combined application of organic plus NPK (15:15:15) fertilizer on the growth parameters of tomato (Lycopersicon esculentum Mill), J. Agric. Hort. Res. 2(1) (2019) 1-5.

[26] A. K. Nafiu, et al., Effects of NPK fertilizer on growth, drymatter production and yield of eggplant in southwestern Nigeria, Agric. Biol. J. N. Am. 2(7) (2011) 1117-1125.

[27] K. Okonwu, S. I. Mensah, Effects of NPK (15:15:15) on some growth indices of pumpkin, Asian J. Agric. Res. 6(3) (2012) 137-143.

[28] P. M. Gloria, et al., Effect of different levels of NPK fertilizer on the growth and yield of okra (Abelmoschus Esculentus L.), Internat. J. Advanced Acad. Res. 3(1) (2017)1-7.

[29] S. M. Kanneh, et al., Response of different NPK fertilizer rates on the growth and yield of two local varieties of pepper (Capsicum annuum L.) in Ogoo Farm, Western Area, Sierra Leone, ARPN J. Agric. Biol. Sci., 12(4) (2017) 123-127.

[30] M. Kumar, et al., Effect of nitrogen, phosphorus and potassium fertilizers on the growth, yield and quality of tomato var. Azad T-6, Asian J. Hort. 8(2) (2013) 616-619.

[31] A. Imran, A. Wahiha, A. K. Zaheer, Effect of different levels of NPK fertilizer on the growth and yield of greenhouse cucumber (Cucumis sativus) by using drip irrigation technology, J. Res. 1(8) (2014) 650-660.

[32] G. O. Nkansah, J. C. Norman, A. Martey, Growth, Yield and Consumer Acceptance of Sweet Pepper (Capsicum annuum L.) as Influenced by Open Field and Greenhouse Production Systems, J. Hort. 4(4) (2017) 1-8. 
[33] F. M. Oloyede, G. O. Agbaje, I. O. Obisesan, Effect of NPK fertilizer on fruit yield and yield components of pumpkin (Cucurbita pepo Linn.), African J. Food Agric. Nutri. Dev. 13(3) (2013) 7755-7771.

[34] F. He, et al., Effects of root cooling on plant growth and fruit quality of cocktail tomato during two consecutive seasons, J. Food Qual. 2019: 1-15.

[35] A. N. M. De Koning, The effects of different day/night temperature regimes on growth, development and yield of greenhouse tomatoes, J. Hortic. Sci. 63 (1988) 465-471.

[36] V. K. Sawhney, P. L. Polowick, Fruit development in tomato: the role of temperature. Can. J. Bot. 63(6) (1985) 1031-1034.

[37] A. P. Papadopoulos, X. Hao, Effects of day and night temperature in early season on growth, productivity and energy use of spring tomato, Can. J. Plant. Sci. 81 (2001) 303-311.

[38] E. M. Khah, H. C. Passam, Flowering, fruit set and development of the fruit and seed of sweet pepper (Capsicum annuum L.) cultivated under conditions of high ambient temperature, J. Hort. Sci. 67 (1992) 251-258.

[39] F. W. Went, Plant growth under controlled conditions. II. Thermoperiodicity in growth and fruiting of the tomato, Amer. J. Bot. 31 (1944) 135-150.

[40] M. Ahumada, M. Cantwell, Post-harvest studies on pepino dulce (Solanum muricatum Ait.): maturity at harvest and storage behavior, Post-harvest Bio. Tech. 7 (1996) 129-136.

[41] A. Cavusoglu, I. E. Erkel, M. Sulusoglu, The effects of climatic factors at different growth periods on pepino (Solanum muricatum Aiton): A model for the enhancement of underutilized exotic fruits, Food Res. Internat. 44 (2009) 1927-1935.

[42] A. Rodriguez-Burruezo, J. Prohens, A. M. Fita, Breeding strategies for improving the performance and fruit quality of the pepino (Solanum muricatum): A model for the enhancement of underutilized exotic fruits, Food Res. Int. 44 (2011) 1927-1935.

[43] M. Gonzales, et al., Colour and composition of improved pepino cultivars at three ripe stages. Gartenbauwissenschaft, 65 (2000) 83-87.

[44] L. Martinetti, F. Paganini, Effect of organic and mineral fertilization on yield and quality of zucchini, Acta Hort. 700 (2006) 125-128.

[45] E. Sanchez, et al., Changes in biomass, enzymatic activity and protein concentration in roots and leaves of green bean plants (Phaseolus vulgaris L. cv. Strike) under high $\mathrm{NH}_{4} \mathrm{NO}_{3}$ application rates, Scientia Hort. 99 (2004) 237-248.

[46] S. O. Omosoto, O. S. Shittu, Effect of NPK fertilizer rate and method of application on growth and yield of okra (Abelmoschus esculentus (L.) Moench) at Ado-Ekiti South western Nigeria, Internat. J. Agric. Res. 2 (2007) 614-619.

[47] J. Prohens, J. J. Ruiz, F. Nuez, Growing cycles for a new crop, the pepino, in the Spanish Mediterranean, Acta Hort. 523 (2000) 53-60.

[48] I. C. Karapanos, S. Mahmood, C. Thanopoulos, Fruit set in solanaceous vegetable crops as affected by floral and environmental factors, The European J. Sci. Biotechn. 2(1) (2008) 88-105

[49] M. M. Peet, D. H. Willits, R. Gardner, Response of ovule development and post-pollen production processes in male- sterile tomatoes to chronic, sub-acute high temperature stress, J. Exp. Bot. 48 (1997) 101-112.

[50] R. K. Raja, V. G. Kakani, Screening capsicum species of different origins for high temperature tolerance in vitro pollen germination and pollen tube length, Scientia Hort. 112 (2007) 130-135.

[51] E. Pressman, R. Shaked, N. Firon, Tomato (Lycopersicon esculentum L.) response to heat stress: focus on pollen grains, Plant Stress, 1 (2007) 216-227.

[52] K. Suzuki, et al., Ultrastructural study on degeneration of tapetum in anther of snap bean (Phaseolus vulgaris L.) cultivar, J. Jpn. Soc. Hortic. Sci. 81 (2001) 251-256.

[53] A. N. Erickson, A. H. Markhart, Flower development and organ sensitivity of bell pepper (Capsicum annum L) to elevated temperature, Plant Cell Environ. 25 (2002) 123-130.

[54] M. Dinar, J. Rudich, Effect of heat stress on assimilate partitioning in tomato, Annals Bot. 56 (1985) 239-248. 
[55] B. Aloni, T. Pashkar, L. Karni, Partitioning of [14]-C sucrose and acid invertase activity in reproductive organs of pepper plants in relation to their abscission under heat stress, Annals Bot. 67 (1991)371-377.

[56] B. Aloni, et al., The susceptibility of pepper (Capsicum annum) to heat induced flower abscission: possible involvement of ethylene, J. Hort. Sc. 69 (1994) 923-928.

[57] Y. Kanayama, A. Kochetov, Abiotic stress biology in horticultural plants, Springer, New York, 2015.

[58] S. Sato, M. M. Peet, J. F. Thomas, Physiological factors limit fruit set of tomato (Lycopersicon esculentum Mill.) under chronic, mild heat stress, Plant Cell Environ. 23 (2000)719-726.

[59] S. Iwahori, High temperature injuries in tomato. IV. Development of normal flower buds and morphological abnormalities of flower buds treated with high temperature, J. Jpn. Soc. Hortic. Sci. 34 (1965) 33-41.

[60] R. Lozano et al., Tomato flower abnormalities induced by low temperatures are associated with changes of expression of MADS-Box genes, Plant Physiol. 117 (1998) 91-100. 